\title{
WYKORZYSTANIE MODELU MIKROSYMULACYJNEGO DO ANALIZY FUNKCJONOWANIA DYNAMICZNEGO PASA AUTOBUSOWEGO
}

\begin{abstract}
W artykule przedstawiono ocenę funkcjonowania dynamicznie wydzielonego pasa autobusowego na wybranym odcinku ulicy w Rzeszowie przy użyciu modeli mikrosymulacyjnych. Artykuł zawiera pełen opis dotyczący wykonanych pomiarów ruchu drogowego na wyznaczonym odcinku. Przedstawiona została zasada działania dynamicznie wydzielanego pasa autobusowego i logika sterowania. $\mathrm{W}$ pracy wykorzystano oprogramowanie komputerowe firmy PTV Vissim do budowy modelu mikrosymulacyjnego. W artykule zamieszczono opis budowy modelu umożliwiającego pełną symulację pasa aktywującego się na potrzeby przejazdu autobusu. W referacie przedstawiono również autorskie podejście umożliwiające kalibrację modeli mikrosymulacyjnych. W wyniku przeprowadzonych prac opracowywano 3 modele ruchu: jeden odzwierciedlający stan aktualny, model odwzorowujący pracę dynamicznie wydzielanego pasa autobusowego oraz model z klasycznym pasem autobusowych. Wykorzystanie modeli mikrosymulacyjnych pozwoliło ocenić korzyści nowego rozwiązania i porównać je z klasycznymi pasami autobusowymi. Analiza czasów przejazdu wzdłuż wydzielonego odcinka pozwoliła zauważyć, że zarówno klasyczne rozwiązanie pasów autobusowych jak i dynamicznie wydzielane pasy autobusowe pozwalają równie efektywnie udzielać priorytetu dla transportu publicznego na odcinku $\mathrm{z}$ wydzielonym pasem autobusowym. Wprowadzenie dynamicznie wydzielanego pasa autobusowego pozwoliło ograniczyć straty czasu na odcinkach poprzedzających i ulicach podporządkowanych. W przeprowadzonej analizie najkorzystniejszy okazał się wariant 3 symulujący dynamicznie wydzielany pas autobusowy. Przeprowadzona mikrosymulacja ruchu pokazała, że dynamicznie wydzielany pas autobusowy nie wpłynie istotnie na pogorszenie czasu przejazdu w transporcie indywidualnym.
\end{abstract}

Słowa kluczowe: wydzielone pasy autobusowe, transport publiczny, mikrosymulacja ruchu, modelowanie ruchu

\section{Wstęp}

Transport autobusowy stanowi ważny, a w wielu miastach jedyny element systemu transportu publicznego. Dlatego istotne jest, żeby działał on sprawnie i stanowił realną i atrakcyjną alternatywę dla transportu samochodowego. Z tego

\footnotetext{
${ }^{1}$ Mateusz Szarata, Politechnika Rzeszowska, Wydział Budownictwa Inżynierii Środowiska i Architektury, Zakład Dróg i Mostów, matsza@ prz.edu.pl
} 
powodu zarządcy miast coraz częściej decydują się na wprowadzanie różnych form priorytetów, w ruchu w tym pasów autobusowych, usprawniających przejazd środków transportowych przez najbardziej zatłoczone ulice w mieście. Zasadność wprowadzenia wydzielonego pasa autobusowego wiąże się $\mathrm{z}$ analizami związanymi z dostępną przestrzenią, odpowiednią wielkością potoków pasażerskich oraz natężeniem ruchu drogowego. Specyfika wielu miejsc może nie uzasadniać wprowadzenia wydzielonych pasów autobusowych na stałe, dlatego coraz częściej spotyka się pasy autobusowe wydzielone czasowo. Przykładem takiego podejścia może być Rzeszów, który w 2015 roku zdecydował się na wprowadzenie pasów autobusowych, przeznaczonych do ruchu autobusów tylko w godzinach szczytu porannego i popołudniowego. Potrzeba czasowego wydzielania pasów autobusowych oraz nowoczesna technologia Inteligentnych Systemów Transportowych (ITS), daje inżynierom nowe możliwości udzielania priorytetu autobusom poprzez zastosowanie Dynamicznie Wydzielanych Pasów Autobusowych (DPA) [1].

Do szczegółowych analiz wydzielonych pasów autobusowych, w tym nowej formy pasów DPA, można wykorzystać modele mikrosymulacyjne [2], które umożliwiają jednoczesne uwzględnienie szeregu parametrów opisujących ruch drogowy, sposób sterowania ruchem i zachowania kierowców. Wiarygodne opisanie ruchu drogowego nie jest zadaniem prostym i wymaga od projektanta zebrania odpowiednich danych umożliwiających określenie rzeczywistych parametrów symulacyjnego modelu ruchu. W zależności od celu i charakteru prowadzonych prac możemy również korzystać z wyjściowych parametrów modelu, ustalonych przez twórców oprogramowania o ile prowadzimy analizy na hipotetycznej sieci drogowej lub chcemy ocenić logikę sterowania sygnalizacją świetlną. Parametry uwzględniane w modelu można podzielić na dwie grupy. Pierwszą grupę stanowią elementy 'stałe', których przeniesienie do modelu nie stwarza problemów. Do tej grupy można zaliczyć geometrię ulic i skrzyżowań, organizację ruchu, programy sygnalizacji świetlnej. Druga grupa parametrów to elementy związane z procesem ruchu drogowego, które pozyskiwane są z obserwacji i pomiarów ruchu. Niestety liczba zmiennych niezbędna do przeprowadzenia symulacji ruchu drogowego jest bardzo duża a w trakcie standardowych pomiarów ruchu ustalane są tylko podstawowe wartości jak natężenie ruchu, struktura kierunkowa, struktura rodzajowa lub czasy przejazdu. Na potrzeby budowy modeli mikrosymulacyjnych ruchu drogowego można zwiększyć zakres pomiarów ruchu i próbować określić inne zmienne związane z zachowaniami kierowców lub warunkami ruchu na skrzyżowaniu. W przypadku gdy ograniczenia finansowe lub czasowe uniemożliwiają nam powiększenie zakresu badań bądź gdy ustalenie dodatkowych parametrów może wiązać się z trudnościami, mamy możliwość skalibrowania parametrów w sposób eksperymentalny.

$\mathrm{W}$ artykule zaproponowano wykorzystanie narzędzi do mikrosymulacji ruchu drogowego $\mathrm{w}$ celu przeprowadzenia analiz funkcjonowania dynamicznie wydzielanych pasów autobusowych. Ponadto przedstawiono podejście, jakie 
może być wykorzystane do kalibracji niektórych parametrów związanych z zachowaniami kierowców w modelach mikrosymulacyjnych. Dzięki zaproponowanej metodzie jesteśmy w stanie uwzględnić dodatkowe czynniki pozwalające dokładniej symulować ruch drogowy z uwzględnieniem lokalnej specyfiki zachowań kierowców.

\section{Infrastruktura ITS dla dynamicznego pasa autobusowego "dziś i jutro"'}

Aktualnie dostępne technologie wykorzystywane przez wiele miast w Polsce umożliwiają w praktyce zarządzanie i sterowanie dynamicznym pasem autobusowym. Istniejąca infrastruktura wymagać będzie jedynie uzupełnienia o dodatkowe elementy obejmujące detekcję autobusów oraz informowania kierowców o aktualnym statusie DPA. Niezbędna będzie również dodatkowa detekcja umożlwiająca analizę aktualnych warunków drogowych, na podstawie których system sterujący pasem będzie podejmować decyzje o włączeniu lub wyłączeniu pasa autobusowego. Jako dodatkowe kryterium aktywacji można przyjąć napełnienie autobusu zbliżającego się do odcinka z priorytetem (tab. 1).

Tabela 1. Zestawienie elementów infrastruktury dynamicznie wydzielanych pasów autobusowych Table 1. Technology and infrastructure for dynamic bus lane

\begin{tabular}{|c|c|c|}
\hline Urządzenia w autobusach & Infrastruktura drogowa & \begin{tabular}{|c|}
$\begin{array}{c}\text { Informacje przesyłane do } \\
\text { sterownika }\end{array}$ \\
\end{tabular} \\
\hline \multirow{4}{*}{$\begin{array}{l}\text { Urządzenia lokalizujące pojazd } \\
\text { np. po przez GPS i telefonię } \\
\text { komórkową, nadajniki radiowe } \\
\text { krótkiego zasięgu (np. w stan- } \\
\text { dardzie } 802.11 \text { p) }\end{array}$} & Sterownik DPA & Położenie autobusów \\
\hline & $\begin{array}{l}\text { Pionowe znaki o zmiennej treś- } \\
\text { ci }\end{array}$ & $\begin{array}{l}\text { Warunki ruchu na odcinku } \\
\text { w tym długość kolejek }\end{array}$ \\
\hline & $\begin{array}{l}\text { Świetlne oznakowanie punkto- } \\
\text { we w jezdni }\end{array}$ & $\begin{array}{l}\text { Bieżący program sygnalizacji } \\
\text { świetlnej }\end{array}$ \\
\hline & Detektory warunków ruchu & *Napełnienie autobusu \\
\hline $\begin{array}{l}\text { Urządzenia zliczające pasaże- } \\
\text { rów }\end{array}$ & $\begin{array}{l}\text { (np. pętle indukcyjne, wideode- } \\
\text { tekcja...) }\end{array}$ & \\
\hline
\end{tabular}

Urządzenia zliczające pasażerów mogą w niedalekiej przyszłości mogą być powszechnie wykorzystywane w transporcie publicznym. Dzięki temu sterownik systemu DPA uzyskałby kolejny parametr na podstawie, którego mógłby podjacć decyzję o aktywacji pasa. Innym rozwiązaniem, które jest obecnie testowane jest komunikacja V2V (vehicle-to-vehicle) i V2I (vehicle-to-infrastructure) umożliwiająca bezpośrednią komunikację pomiędzy pojazdami indywidualnymi a na przykład transportem publicznym. Wykorzystanie tej formy komunikacji sprawdzono w 2009 roku w ramach programu CVIS ( Cooperative Vehicle Infrastructure Systems) w Bolonii [3]. Celem programu była ocena efektywności rozwiązania umożliwiającego warunkowe korzystanie $\mathrm{z}$ wydzielonych dla autobusów ulic przez pojazdy wyposażone w system łączności między pojazdami (V2V) lub mię- 
dzy pojazdami a infrastrukturą (V2I). Korzystanie z odcinka testowego, poprowadzonego przez wydzieloną ulicę autobusową, umożliwiało skrócenie czasu dojazdu do centrum o 5 min w porównaniu do przejazdu ulicą ogólnodostępną. Zbliżający się do wydzielonego odcinka pojazd wyposażony w system V2I i V2V otrzymywał informację o możliwości lub braku możliwości przejazdu. System przekazujący informację do pojazdu analizował położenie autobusów i w sytuacji, kiedy odcinek był pusty zezwalał na wjazd. Określenie dokładnej lokalizacji autobusów było możliwe dzięki systemowi GPS, w który zostały one wyposażone.

\section{Logika sterowania}

System dynamicznie wydzielanego pasa autobusowego działa $\mathrm{w}$ dwóch stanach: w stanie uśpionym i w stanie aktywnym. System znajduje się w stanie uśpio-

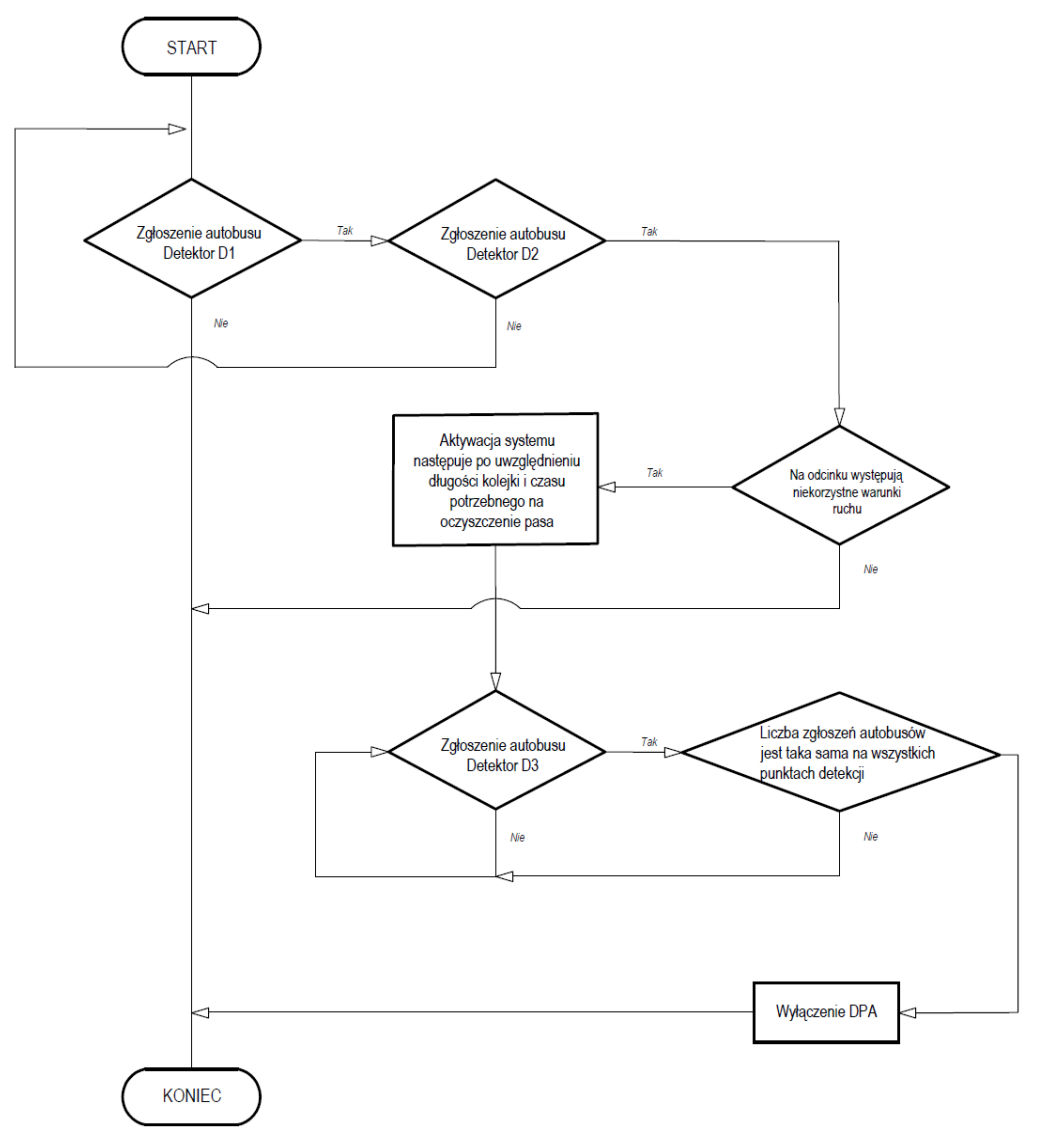

Rys. 1. Logika sterowania dynamicznie wydzielanym pasem autobusowym

Fig. 1. Logic control for dynamic bus lane 
nym gdy warunki ruchu drogowego są dobre i nie wpływają niekorzystnie na czasy przejazdu autobusów lub żaden z autobusów nie ma potrzeby skorzystania z przejazdu (rys. 1.). DPA aktywuje się dopiero w sytuacji gdy do odcinka, na którym panują niekorzystne warunki ruchu zbliża się autobus. Detekcja pojazdów transportu publicznego wymaga zdefiniowania minimum 3 punktów. Są to :

- Pierwszy punkt detekcji (pełni rolę potrzymania aktywnego pasa) D1,

- Drugi punkt detekcji (aktywujący pas autobusowy) D2,

- Punkt końcowy (zlokalizowany na końcu odcinka) D3.

Pierwszą informację o zbliżającym się autobusie przesyła detektor D1. Informacja pochodząca $z$ tego detektora jest niezbędna przy podejmowaniu decyzji związanej z wyłączeniem dynamicznego pasa autobusowego. Decyzja o aktywacji pasa zostanie podjęta gdy pojazd dotrze do drugiego punktu aktywacji oraz gdy warunki na wyznaczonym odcinku będą wpływać niekorzystnie na czas przejazdu. W momencie gdy autobus dociera do ostatniego punktu system weryfikuje poprzez punktu D1 czy do odcinka zbliżają się nowe autobusy. Odpowiednia lokalizacja tego punktu pozwoli z odpowiednim wyprzedzeniem podtrzymać pas aktywny nie powodując przy tym niepotrzebnych krótkotrwałych okresów dezaktywacji. System zostanie wyłączony dopiero wtedy gdy liczba zgłoszeń na wszystkich detektorach będzie taka sama.

\section{Pomiary ruchu}

Do przeprowadzenia analiz funkcjonowania dynamicznie wydzielanego pasa autobusowego wybrano 850 m odcinek ul. Podkarpackiej w Rzeszowie. Przekrój ulicy składa się z dwóch jezdni z dwoma pasami ruchu każda. Na odcinku znajdują się dwa przystanki autobusowe, z których w godzinach szczytu korzysta do 11 autobusów na godzinę. W 2015 roku na wytypowanym odcinku przeprowadzono pomiary ruchu obejmujące:

- pomiar natężenia ruchu,

- określenie średniego czasu przejazdu pojazdów indywidualnych,

- pomiar czasu przejazdu w transporcie publicznym.

Dodatkowo w rejonie skrzyżowań z sygnalizacją świetlną ustawiono kamery z szerokokątnym obiektywem umożliwiające zapis warunków ruchu i specyfiki zachowań kierowców. Wybrany fragment ulicy Podkarpackiej podzielono na dwa pododcinki. Pierwszy o długości $630 \mathrm{~m}$ rozpoczyna się od skrzyżowania z sygnalizacją świetlną z ul. Matuszczaka a kończy na skrzyżowaniu z sygnalizacją świetlną z ul. Poznańską. Drugi pododcinek o długości $220 \mathrm{~m}$ rozpoczyna się na skrzyżowaniu z ul. Poznańską a kończy na skrzyżowaniu z aleją Powstańców Warszawy. Pomiar natężenia ruchu został przeprowadzony w kierunku do Centrum w godzinach szczytu popołudniowego (od 14:00 do 17:00) na wlotach 3 skrzyżowań z sygnalizacją świetlną zlokalizowanych na odcinku. W trakcie pomiarów obserwatorzy odnotowywali natężenie ruchu na poszczególnych relacjach oraz strukturę rodzajową pojazdów (rys. 2). 


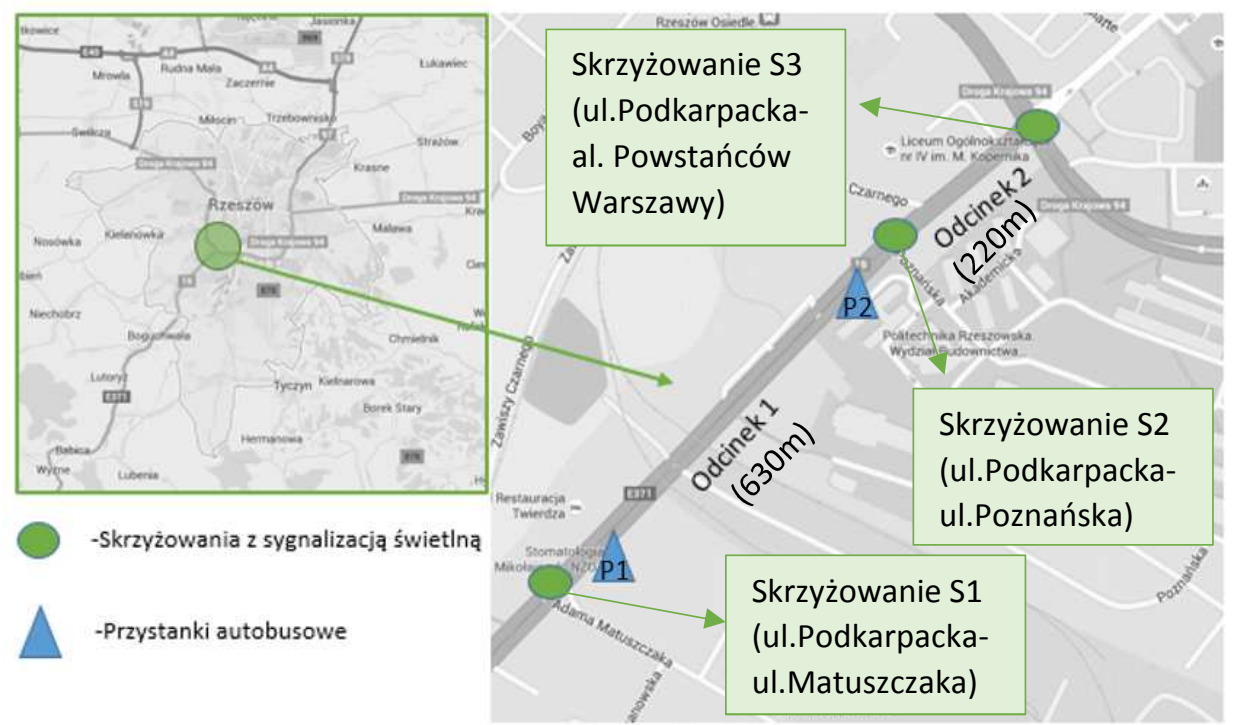

Rys. 2. Lokalizacja odcinka (na podstawie mapy Google)

Fig. 2. The location of section (by Google maps)

Do budowy modelu mikrosumulacyjnego wykorzystano natężenie ruchu z godziny szczytu (14:45 do 15:45). Na pierwszym odcinku w godzinie szczytu zanotowano $1093 \mathrm{P} / \boldsymbol{h}$ a na drugim odcinku za skrzyżowaniem z ulicą Poznańską $1542 \mathrm{P} / \boldsymbol{h}$. Pomiar czasu przejazdu realizowany był metodą notowania tablic rejestracyjnych. Dodatkowo przy wyznaczaniu czasu przejazdu w transporcie publicznym zapisywano czas związany z wymianą pasażerów na poszczególnych przystankach. Wyznaczony w ten sposób średni czas przejazdu pojazdów indywidualnych wyniósł $232 s$ na odcinku 1 oraz $145 s$ na odcinku 2 w przyjętej godzinie szczytu. W transporcie autobusowym czasy przejazdu w godzinie szczytu wyniosły odpowiednio: 331 s na odcinku 1 i 178 s na odcinku 2.

\section{Mikrosymulacyjny model ruchu drogowego}

Określenie potencjalnych korzyści z wprowadzenia nowego rozwiązania dla wydzielenia pasa autobusowego wymaga przeprowadzenia szeregu analiz. Bardzo dobre efekty w ocenie działania dynamicznych pasów autobusowych otrzymuje się wykorzystując modele mikrosymulacyjne ruchu drogowego. Komputerowe modele ruchu pozwalają na przeprowadzenie symulacji uwzględniającej wiele czynników jednocześnie w tym pracę systemu sterowania DPA. Opracowane modele ruchu umożliwiają między innymi porównanie średnich czasów przejazdu zarówno w transporcie publicznym jak i w prywatnym. Przykładem wykorzystania mikrosymulacyjnych modeli ruchu do oceny efektywno- 
ści DPA przed implementacją może być odcinek testowy w Lizbonie, gdzie otrzymane w modelu wyniki średnich czasów przejazdu różniły się 5\% od czasów przejazdów pomierzonych po wprowadzeniu DPA [4].

Analizy dynamicznie wydzielanego pasa autobusowego zostały wykonane w programie komputerowym do przeprowadzania mikrosymulacji ruchu Vissim firmy PTV. Budowa wiarygodnego modelu ruchu, który zostanie wykorzystany do analiz wymaga odzwierciedlenia istniejącego układu drogowego oraz warunków ruchu. Następnie model skalibrowany w sposób opisany w pkt. 5.1.2 został wykorzystany do analiz wprowadzenia wydzielonych pasów autobusowych w następujących konfiguracjach:

- wariant 1 - przedstawiający aktualną organizację ruchu,

- wariant 2 - zakładający wprowadzenie klasycznego czasowego pasa autobusowego, wydzielanego w godzinach szczytu,

- wariant 3 - zakładający wprowadzenie dynamicznie wydzielanego pasa autobusowego.

Przyjęte w wariancie 2 i 3 rozwiązanie nowej organizacji ruchu uwzględniło specyfikę odcinka, zmiany w przekroju ulicznym, które występują w rejonach skrzyżowań i pomiędzy odcinkami 1 i 2 . Ostatecznie do modelu ruchu na odcinku 1 wprowadzono wydzielony pas dla autobusów o długości $350 \mathrm{~m}$. Pas autobusowy rozpoczyna się przy przystanku P1 a kończy $120 \mathrm{~m}$ przed skrzyżowaniem na wysokości przystanku P2. Autobusy wyjeżdżające z przystanku P2 jadące na wprost mogą wykorzystywać pas do skrętu w prawo, który cechuje się niskim stopniem wykorzystania przepustowości. Dzięki temu w przyjętym rozwiązaniu autobus od momentu wjazdu na pas autobusowy do momentu wyjazdu z odcinka 1 może poruszać się bez przeszkód.

\subsection{Budowa modelu bazowego -wariant 1}

\subsubsection{Budowa sieci drogowej}

Proces budowy modelu bazowego zakłada odzwierciedlenie istniejącej geometrii odcinka, w tym liczby i szerokości pasów ruchu oraz promieni łuków poziomych. W kolejnym kroku wprowadzono odpowiednią organizacje ruchu i elementy sterowania ruchem. Następnie wykorzystując dane z pomiarów zadano odpowiednie natężenie ruchu, strukturę kierunkową oraz strukturę rodzajową z podziałem na 7 grup pojazdów (Sam. Osobowe, Sam. Dostawcze, Sam. Ciężarowe, Sam. Ciężarowe z Przyczepami, Autobusy, Motocykle, Pojazdy Rolnicze). Wprowadzenie pełnej struktury rodzajowej wymagało dodania nowych typów pojazdów reprezentujących poszczególne grupy.

\subsubsection{Kalibracja modelu ruchu}

Bardzo ważnym czynnikiem w procesie budowy modelu ruchu jest kalibracja zachowań kierowców. Pozwala ona na odwzorowanie charakterystycznych 
zachowań w ruchu drogowym dla analizowanego odcinka. Do przeprowadzenia kalibracji wybrano model Wiedemann 74', który najlepiej nadaje się do symulacji ruchu miejskiego [5]. Wybrany model ruchu umożliwia kalibracje kilkunastu parametrów. Na podstawie przeprowadzonego przeglądu literaturowego [5][6][7][8] wytypowano grupę 7 parametrów oraz zakres w jakim mogą się one zmieniać (tabela 2).

Kalibrację wartości parametrów zachowań kierowców pojazdów przeprowadzono metodą eksperymentalną, w której przyjęto, że wybrany do dalszych analiz zestaw powinien spełniać następujące wymagania:

- różnica średniego czas przejazdu dla pojazdów indywidualnych i autobusów na poszczególnych odcinkach w modelu nie powinna różnić się więcej niż o 15\% od czasów zanotowanych podczas pomiarów ruchu,

- wartość wskaźnika GEH wyznaczonego według wzoru (1), określająca zgodność natężeń ruchu otrzymanych w modelu z natężeniami ruchu pomierzonymi w terenie nie powinna przekroczyć 5 (zgodnie z wytycznymi [8]):

$$
G E H=\sqrt{\frac{2(E-V)^{2}}{(E+V)}}
$$

gdzie: $E$ - natężenie ruchu wyznaczone w modelu mikrosymulacyjnym $(P / h)$,

$V$ - natężenie ruchu pomierzone na odcinku $(P / h)$.

W pierwszym kroku wylosowano zestaw 36 kombinacji parametrów dla przyjętego zakresu (tab. 2).

Na tym etapie głównym celem było odrzucenie najmniej korzystnych parametrów dlatego dla każdej z kombinacji wykonano po 5 symulacji dla różnych liczb losowych (random seeds). Zmiana parametru 'random seeds', umożliwia między innymi losową generacje zgłoszeń pojazdów w przekroju w każdej kolejnej symulacji. Dzięki temu jesteśmy w stanie uwzględnić losowy ruch pojazdów na analizowanym odcinku. W każdej z symulacji przewidziano 15 min czas początkowy, potrzebny do napełnienia modelu pojazdami i odwzorowaniu warunków ruchu najbliższych do tych, które występowały na początku wyznaczonej godziny szczytu. Po tym okresie rozpoczynał się właściwy pomiar. Do kolejnego etapu wytypowano te kombinacje, których różnice wartości średnich czasów przejazdu i natężenia ruchu nie przekraczały 30\%. Dla wytypowanych zestawów ponownie przeprowadzono 40 krotne symulacje dla zmiennych liczb losowych. Założenia kalibracji początkowo spełniało 5 zestawów parametrów. Przed wyborem ostatecznego zestawu przeprowadzono analizę wizualną symulacji, której celem było wskazanie tych zestawów parametrów, przy których zachowania pojazdów są zgodne $\mathrm{z}$ zachowaniami kierowców obserwowanymi na odcinku. Przeprowadzona obserwacja wprowadziła zmianę 1 parametru dla wszystkich zestawów. Zauważono, że wylosowane wartości, które nie przekraczały $7 \mathrm{~m}$ dla awaryjnego punktu zatrzymań w celu zmiany pasa ruchu powodowały, że pojazdy zatrzymywały się na samej tarczy skrzyżowania blokując $w$ ten 
Tabela 2. Parametry uwzględnione w procesie kalibracji

Table 2. Identification of Calibration Parameters

\begin{tabular}{|c|c|c|c|c|c|}
\hline$\dot{\mathbf{z}}$ & Parametr & 惫 & 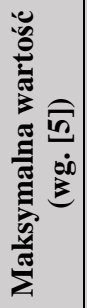 & 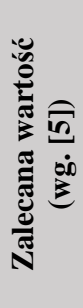 & 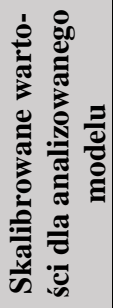 \\
\hline 1 & $\begin{array}{l}\text { Emergency Stopping Distance - awaryjna odległość } \\
\text { zatrzymania, po osiągnięciu której pojazd się za- } \\
\text { trzymuje i oczekuje na możliwość wjazdu na odpo- } \\
\text { wiedni pasa ruchu, taka sytuacja może mieć miejsce } \\
\text { gdy na przyjętym odcinku zmiany pasa ruchu pojazd } \\
\text { nie mógł wjechać na wybrany pas z powodu dużego } \\
\text { natężenia ruchu [m] }\end{array}$ & 2 & 7 & 5 & 20 \\
\hline 2 & $\begin{array}{l}\text { Lane Change Distance - odległość zmiany pasa } \\
\text { ruchu (np. przed skrzyżowaniem), od której pojazdy } \\
\text { ustawiają się na wybranych pasach w celu kontu- } \\
\text { nuowania jazdy wzdłuż przyznanych ścieżek ruchu } \\
{[\mathrm{m}]}\end{array}$ & 150 & 300 & 200 & 200 \\
\hline 3 & $\begin{array}{l}\text { Desired Speed Distribution- prędkość w ruchu nie- } \\
\text { zakłóconym; przyporządkowywana jest pojazdom } \\
\text { z odchyleniem } 10 \% \text { od wskazanej wartości }[\mathrm{km} / \mathrm{h}]\end{array}$ & 60 & 80 & 70 & 60 \\
\hline 4 & $\begin{array}{l}\text { Number of Observed Preceding Vehicles - Liczba } \\
\text { obserwowanych pojazdów znajdująca się przed } \\
\text { poruszającym się pojazdem wpływająca na zacho- } \\
\text { wania kierowcy tego pojazdu [P] }\end{array}$ & 1 & 4 & 2 & 3 \\
\hline 5 & $\begin{array}{l}\text { Average Standstill Distance- średnia odległość po- } \\
\text { między pojazdami stojącymi w kolejce lub od punk- } \\
\text { tów stałych (linie zatrzymań) [m] }\end{array}$ & 1 & 3 & 2 & 3 \\
\hline 6 & $\begin{array}{l}\text { Waiting Time Before Diffusion - czas oczekiwania } \\
\text { po którym następuje usunięcie zablokowanego mo- } \\
\text { delu z symulacji [s] }\end{array}$ & 20 & 60 & 60 & 60 \\
\hline 7 & $\begin{array}{l}\text { Minimum Headway - minimalna odległość przed } \\
\text { pojazdem umożliwiająca zmianę pasa ruchu [m] }\end{array}$ & 0,5 & 7 & 1,5 & 3 \\
\hline
\end{tabular}

sposób ruch. Dlatego wartość tego parametru zwiększono tak, aby punkt ten wypadał przed przejściem dla pieszych na wlocie. Dla wprowadzonej zmiany ponownie wykonano serię 40 symulacji. Do modelu bazowego przyjęto ten który wykazał największą zgodność z przeprowadzonymi pomiarami ruchu (tabela 3$)$. 
Tabela 3. Wyniki kalibracji modelu

Table 3. The results of model calibration

\begin{tabular}{|c|c|c|c|c|c|}
\hline & Odcinek & $\begin{array}{c}\text { Średni czas } \\
\text { przejazdu (s) } \\
\text { - obserwacje }\end{array}$ & $\begin{array}{c}\text { Średni czas } \\
\text { przejazdu (s) } \\
\text { - model }\end{array}$ & $\begin{array}{c}\text { Różnica } \\
\text { czasów prze- } \\
\text { jazdów (\%) }\end{array}$ & $\begin{array}{c}\text { Wartość } \\
\text { wskaźnika } \\
\text { GEH }\end{array}$ \\
\hline $\begin{array}{c}\text { Pojazdy } \\
\text { indywidualne }\end{array}$ & Odcinek 1 & 232 & 225 & 3 & 2,4 \\
\cline { 2 - 6 } Autobusy & Odcinek 2 & 145 & 124 & 14 & 0,8 \\
\cline { 2 - 5 } & $\begin{array}{c}\text { P1-P2 } \\
\text { Pkrzyżowa- } \\
\text { nie nr3 }\end{array}$ & 226 & 206 & 9 & \multirow{2}{*}{ - } \\
\hline
\end{tabular}

\subsection{Modele zakładające wprowadzenie wydzielonych pasów autobusowych (wariant 2 i wariant 3)}

Sieć drogowa modelu ruchu w programie PTV Vissim, składa się z odcinków i łączników. Odcinki umożliwiają odwzorowanie przebiegu i geometrii ulic. Łączniki stosowane są w celu łączenia odcinków ulic dochodzących do skrzyżowań lub wprowadzania dodatkowych pasów ruchu. Opracowanie modelu ruchu zakładającego wariant pasów autobusowych wydzielonych na stałe, było możliwe dzięki zdefiniowaniu parametru dostępu wybranej grupy pojazdu dla pasa ruchu na odcinku. W ten sposób na skrajnym prawym pasie ruchu umożliwiono wjazd autobusom a na lewym pasie ruchu umożliwiono poruszanie się pozostałym grupom pojazdów. W celu przeprowadzenia symulacji dynamicznie wydzielanego pasa autobusowego rozwinięto model $\mathrm{z}$ wydzielonym pasem autobusowym. Przyjęcie standardowego podejścia umożliwiającego zdefiniowania grupy pojazdów korzystających z poszczególnych pasów nie było możliwe z uwagi na brak możliwości zmiany dostępu do poszczególnych pasów ruchu w trakcie symulacji. Dlatego przyjęto niestandardowe podejście definiowania ścieżek przejazdu $\mathrm{w}$ trakcie symulacji. W tym celu w modelu wprowadzono następujące modyfikacje (rys. 3):

- wprowadzono dodatkowy podziału istniejącego odcinka w miejscach gdzie pas autobusowy się rozpoczynał i kończył,

- wstawiono dodatkowe łączniki umożliwiające wjazd i wyjazd tylko na ogólnodostępny pas ruchu,

- wyznaczono na nowo ścieżki (vehicle routes) dla pojazdów prywatnych przechodzących przez nowy łącznik ( autobusom umożliwiono korzystanie ze standardowego łącznika dopuszczającego wjazd na wydzielony pas ruchu),

- zdefiniowano reguły wymuszające zmianę pasa ruchu (lane change) w odległości większej niż podzielony odcinek, co pozwoliło uniemożliwiło zmianę pasów ruchu pojazdom indywidualnym w trakcie aktywnego pasa autobusowego. 


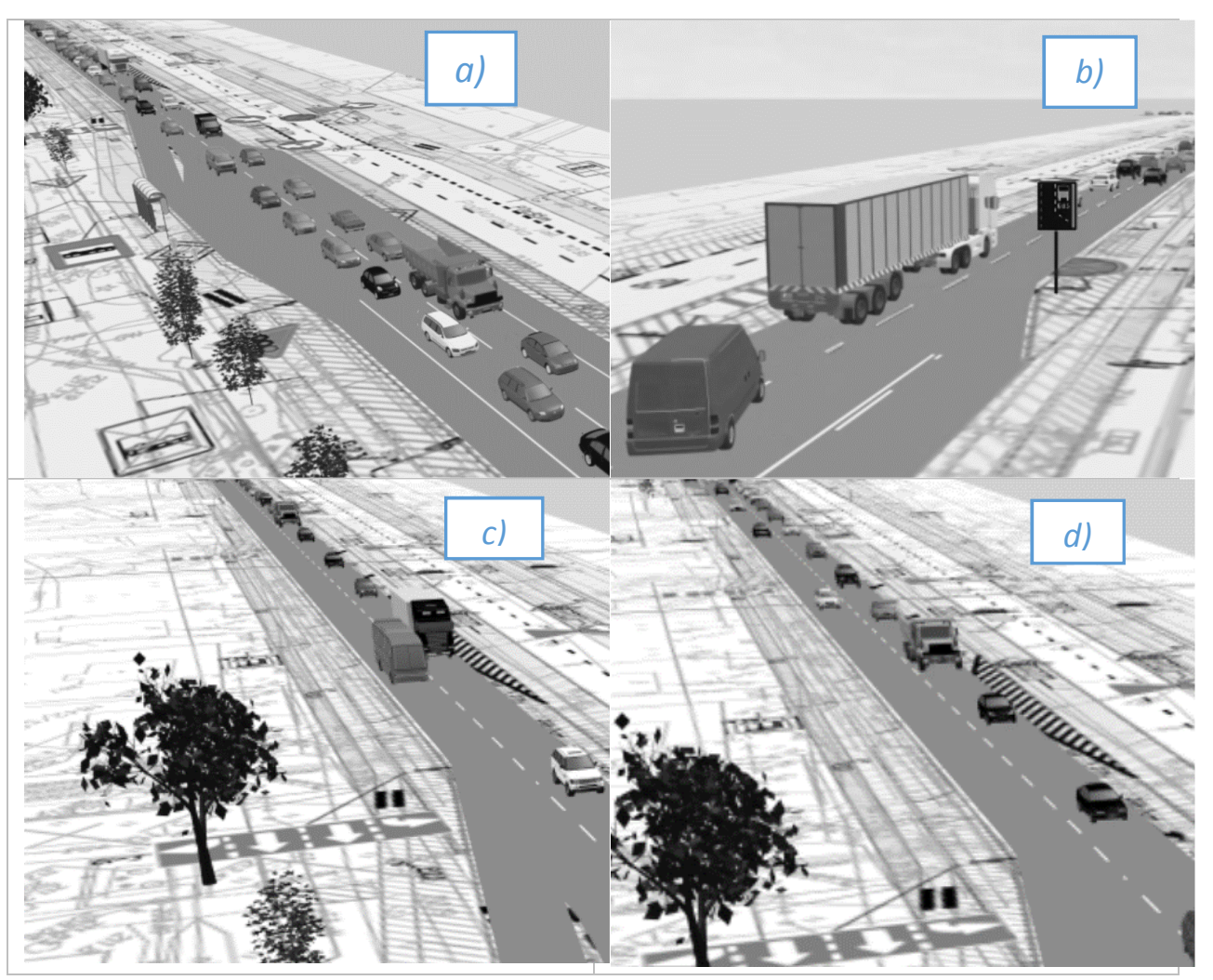

Rys. 3. Symulacja aktywacji dynamicznego pasa autobusowego: a) pas nieaktywny, b) etap aktywacji pasa, c) przejazd wydzielonym pasem autobusowym, d) dezaktywacja pasa

Fig. 3. Dynamic bus lane simulation: a) bus lane inactive, b) activation of bus lane, c) DBL active, d) deactivation

Wyznaczenie punktów przełączeń pomiędzy pasem aktywnym a nieaktywnym opracowano na podstawie wielokrotnie przeprowadzanych symulacji, w trakcie których wyznaczano m.in. czas oczyszczenia pasa ruchu. Czas oczyszczenia pasa ruchu zmieniał się od 170s do 270s w zależności od długości kolejek tworzących się na wlocie skrzyżowania. Otrzymane w ten sposób czasy pozwoliły opracować strategię działania DPA. Odrzucono możliwość aktywacji pasa na potrzeby przejazdu poszczególnego autobusu ponieważ, w niektórych przypadkach autobusy pojawiały się co 5 min lub częściej. W tej sytuacji pomimo kilkuminutowej przerwy pomiędzy przyjazdem kolejnych autobusów pozostawiono aktywny pas. Ostatecznie wyznaczono 4 przedziały czasowe aktywacji pasa na łączny czas $31 \mathrm{~min}$, udzielając tym samym priorytetu 8 autobusom. 


\section{Wyniki badań}

Wprowadzenie wydzielonych pasów autobusowych na odcinku 1 i 2 przyczyniło się do skrócenia średnich czasów przejazdu (tab.4). Ma to związek z porządkowaniem się ruchu oraz 'efektem bramkowania', w wyniku którego pogarszają się warunki ruchu na odcinku poprzedzającym wydzielony pas autobusowy a poprawiają na odcinku gdzie pas został wprowadzony. Dlatego do podsumowania proponowanego rozwiązania, wstawiono dodatkowy punkt pomiarowy uwzględniający łączny czas przejazdu wzdłuż całego modelu. Wpływ pasów autobusowych na czas przejazdu pojazdów indywidualnych różnił się w zależności od analizowanego wariantu. Klasyczne rozwiązanie powodowało zwiększenie strat czasu przejazdu na całym odcinku przejazdu o $12 \%$ natomiast dynamicznie wydzielany pas autobusowy umożliwił skrócenie czasów przejazdu o $31 \mathrm{~s} \mathrm{w}$ stosunku do wariantu 2. Analizując czasy przejazdu wzdłuż wydzielonego odcinka można zauważyć, że zarówno klasyczne rozwiązanie pasów autobusowych jak i DPA pozwalają równie efektywnie udzielać priorytetu dla transportu publicznego. Analiza czasu przejazdu dla całego modelu obejmująca odcinki początkowe pokazuje, że największe korzyści dla transportu publicznego przyniesie wariant $\mathrm{z}$ dynamicznie wydzielonym pasem autobusowym. Dzięki temu rozwiązaniu średnie długości kolejek i straty czasu na wlotach podporządkowanych są znacznie mniejsze w stosunku do klasycznego rozwiązania. DPA pomaga szybciej i sprawniej dostać się autobusom na wydzielony dla nich pas. Wprowadzenie wariantu 2 zwiększyło czas dojazdu z drogi podporządkowanej (ul. Matuszczaka, rys.2.) do punktu rozpoczęcia się pasa autobusowego ponad czterokrotnie.

Tabela 4. Wyniki mikrosymulacji ruchu

Table 4. Results of microsimulation

\begin{tabular}{|l|c|c|c|}
\hline \multicolumn{5}{|c|}{ Średnie czasy przejazdu - transport indywidualny } \\
\hline Odcinek & Wariant 1 & Wariant 2 & Wariant 3 \\
\hline Odcinek poczatkowy & $390 \mathrm{~s}$ & $619 \mathrm{~s}$ & $468 \mathrm{~s}$ \\
\hline Odcinek 1 & $202 \mathrm{~s}$ & $120 \mathrm{~s}$ & $142 \mathrm{~s}$ \\
\hline Odcinek 2 & $121 \mathrm{~s}$ & $58 \mathrm{~s}$ & $110 \mathrm{~s}$ \\
\hline $\begin{array}{l}\text { Caty model (tacznie z odcinkiem poczatkowym } \\
\text { ul. Podkarpacka) }\end{array}$ & $713 \mathrm{~s}$ & $797 \mathrm{~s}$ & $720 \mathrm{~s}$ \\
\hline \multicolumn{4}{|c|}{ Średnie czasy przejazdu - transport publiczny } \\
\hline Odcinek poczatkowy & $57 \mathrm{~s}$ & $232 \mathrm{~s}$ & $100 \mathrm{~s}$ \\
\hline P1-P2 & $180 \mathrm{~s}$ & $119 \mathrm{~s}$ & $119 \mathrm{~s}$ \\
\hline P2-skrzyżowanie nr3 & $179 \mathrm{~s}$ & $100 \mathrm{~s}$ & $161 \mathrm{~s}$ \\
\hline $\begin{array}{l}\text { Caty model (tacznie z odcinkiem poczatkowym } \\
\text { na ul. Matuszczaka) }\end{array}$ & $416 \mathrm{~s}$ & $451 \mathrm{~s}$ & $380 \mathrm{~s}$ \\
\hline
\end{tabular}




\section{Wnioski}

Modele mikrosymulacyjne umożliwiają przeprowadzenie analiz niestandardowych rozwiązań organizacji ruchu drogowego. Szczególnie nadają się do analiz nowych rozwiązań jakim są dynamicznie wydzielane pasy autobusowe. Budowa modeli mikrosymulacyjnych wymaga jednak nie tylko dokładnego odwzorowania geometrii układu drogowego i potoków ruchu, ale również zachowań kierowców, które w istotny sposób wpływają na wyniki symulacji. Dzięki możliwości przeprowadzenia pełnej symulacji aktywacji i dezaktywacji pasa możliwa jest ocena rozwiązania i porównanie go $\mathrm{z}$ inną formą priorytetu. Ponadto symulacja ruchu drogowego pozwala na opracowanie i zoptymalizowanie logiki sterowania dynamicznie wydzielanego pasa autobusowego. W dalszych pracach niezbędne będzie przeprowadzenie symulacji, w których dopracowana zostanie logika sterowania uwzględniająca detekcje autobusów i pojazdów na podstawie, której aktywacja i dezaktywacja pasa będzie odbywać się automatycznie bez udziału projektanta.

W przeprowadzonej analizie najkorzystniejszy okazał się wariant 3 dynamicznie wydzielany pas autobusowy. W podsumowaniu analiz efektywności uwzględniono warunki ruchu na samym odcinku oraz na odcinku początkowym (dojazdowym). Zauważono, że rozwiązanie z DPA generowało mniejsze kolejki na wlotach podporządkowanych dróg w porównaniu do klasycznego rozwiązania pasa autobusowego. Przeprowadzona mikrosymulacja ruchu pokazała, że dynamicznie wydzielany pas autobusowy nie wpłynie istotnie na pogorszenie czasu przejazdu w transporcie indywidualnym.

\section{Literatura}

[1] Szarata M.: Analiza wprowadzenia dynamicznie wydzielanego pasa autobusowego, Wybrane interdyscyplinarne zagadnienia budownictwa, (pod red.) R. Nagórski s. 5564, Warszawa 2015.

[2] Szarata M.: Wybrane metody modelowania dynamicznie wydzielanych pasów autobusowych, Transport Miejski I Regionalny, 12/2014.

[3] Vreeswijk J., Armandi M., Campello P., (2008), Flexible bus lanes in Bologna, ITS Europe Geneva, 2008.

[4] Viegas J. M., Roque R., Lu B.,Vieira J., The Intermittent Buslane System: demonstration in Lisbon, in 86th Transportation Research Board Annual Meeting, Washington, DC, 2007.

[5] Podręcznik użytkownika Vissim 5.2. PTV Vision 2009.

[6] Byungkyu Park, J. D. Schneeberger Microscopic Simulation Model Calibration and Validation, Transportation Research Record 1856, Paper No. 03-2531.

[7] Dybicz T.: Odwzorowanie fenomenu dwóch przepustowości w mikrosymulacyjnym modelu ruchu w programie Vissim, Zeszyty Naukowo-Techniczne SITK RP, Oddział w Krakowie 2014, s. 41-55.

[8] Dowling R., Skabardonis A., Alexiadis V.; Traffic Analysis Toolbox Volume III: Guidelines for Applying Traffic Microsimulation Modeling Software, Federal Highway Administration 2003. 


\section{APPLICATION MICROSCOPIC SIMULATION MODEL FOR DYNAMIC BUS LANE}

\section{S u m m a r y}

One of the most effective solution to increase the attractiveness of public transport is dedicated bus lane, that allow buses to smooth move along the streets. A major limitation of this solution is impact on road capacity and traffic congestion. In the case of not enough passenger flow, the solution is not used and the buses are experiencing delays. Dynamic bus lane with intermittent priority can be an alternative solution. The paper presents an assessment of dynamic bus lane on selected street in Rzeszow. The study was based on microsimulation models developed with PTV Vissim software. Author propose a procedure for calibration and validation microscopic simulation model. In order to determine the effectiveness of the dynamic bus lane, three option were analyzed: Option 0 is a baseline variant with current traffic organization, Option 1 is option with standard bus lane and Option 2 is option with dynamic bus lane. The paper also presents operating principles of bus lane with intermittent priority and results of traffic surveys conducted in Rzeszow. The analysis shows that compared to the standard bus lane, the use of bus lane with intermittent priority can bring more benefits. Performed traffic microsimulation showed that dynamic bus lane does not have a significant impact on private transport travel time LOS.

Przestano do redakcji: $10.12 .2016 r$.

Przyjęto do druku: 31.03.2017 r. 